\title{
Research on Technical Capacity Promotion of Export-oriented Private Enterprises
}

\author{
Hua Zou \& Zhe Cao \\ School of Management \\ Shenyang University of Technology \\ Shenyang 110178, China \\ E-mail: suo-2001@163.com
}

\begin{abstract}
How to evaluate the technical capacity of export-investment enterprises objectively, scientifically and effectively, it is valuable for export-oriented private enterprises to locate technology innovation goals themselves, develop implementation of technical innovation successfully, keep and enhance competitive advantage, and get the best economy and social benefits. On the basis of definition related, the article analyzes the status and issue of technical innovation of export-oriented private enterprises, researches the model of updating technical capacity deeply, and gives the appropriate measures in macro and micro level.
\end{abstract}

Keywords: Export-oriented, Technical capacity, Upgrade

How is the export-oriented private enterprise in long-time competition in the domestic and foreign markets with the process of Chinese economic reforms accelerating and meeting the need of international and domestic economic situation? It depends on the ability of transnational factors of production and technical advancement.

\section{Concepts Related}

Export-oriented enterprises mean export-oriented export enterprises whose basic production process based on domestic, commodity exchanging faced international market and it participated in international division of labor and international competition positively.

Private enterprises refer to economic organizations making profit which are set up or held by a natural person and based on employing.

Export-oriented private enterprise(Zhang, 2001, pp.23-25) is a business obtaining foreign exchange which is set up or held by a natural person, based on employing, taking the technical advancement as the backing and the international market as the guidance. It develops the international market by competitive products or service of high-quality and it enhances continuous competitive ability in the international market through conformity element of production to achieve an export-oriented technology and economic virtuous circle.

Technical capability refers that enterprise creates technology unique to get ability which is hard to imitate for outsiders and scarce by specific technical elements and skills or a unique combination.

\section{Existing problems about technical innovation of the export-oriented private enterprises}

With the need of reform, the development of Chinese technical innovation, especially export-oriented private enterprises, is a great progress. While generally speaking, business is not aware of knowledge, technology and talent. Most enterprises are also accustomed to ignore the changes in the mode of growth and there are more problems about innovation in technology upgrading, market adaptability and key technology.

\subsection{Weak awareness of technical innovation}

Because of limited funds and weak awareness of the role of technical capacity, technical capacity of most export-oriented private enterprises is weaker. They are also lack of core technology and easy to be imitated. (Zhang, 2001, pp.23-25).Addition, they only spend funds on sale strategy at the most time.

\subsection{Technological innovation in small enterprises}

The cost of technical development and R \& D expenditure are important indicators which measure strength of technical 
innovation. The international community generally believes that only R \& D expenditures accounted for 2 percent of sales, enterprises can survive. And it reaches 5\%, enterprises are competitive. (Zhang, 2001, pp.23-25).Compared with developed countries(an average of $2 \%$ to $3 \%$ ), $\mathrm{R} \& \mathrm{D}$ expenditure of our country is lower than $1.5 \%$. At the same time ,most businesses have not yet regarded the development of innovation through a developing thought. They fail to connect product innovation and technical innovation with economic efficiency and market competition. See Figure 1.

Insert Figure 1 Here

\subsection{Incentive mechanism of technical innovation has not yet formed}

Most export-oriented private enterprises don't deeply understand the relationship between technical advancement and competitive power. Addition, demanding of scientific and technical achievements is not strong. Though some need, they are unable to pay transfer fees. The result is enterprises can not rely on technical innovation to adapt to market competition.

\section{Development model of the technical capacity}

\subsection{Model of independent innovation}

Here, independent innovation model is a model which is based on project combination and the future improvement of technical capacity. (Mao, 2000, pp.4-6). This pattern has strong independence, high input, high risk and the slow process of technology accumulation. Therefore, the export-oriented private enterprises should have strong financial strength, strong research and development ability, knowledge accumulation and advantages in the colleague in this mode. See table 1.

\subsection{Model of cooperation innovation}

Judging from present situation of our country, export-oriented private enterprises are mostly small and medium scale. Their own resources and capacity of research and development are weak. So, this model is more suitable. Cooperation innovation model (Mao, 2000, pp.4-6) is based on mixed-mode technology of project combination. Therefore, an inevitable trend of technical innovation is to carrying on the independent research and development and the significant technical innovation by enterprise's division of labor and cooperation's way, realizing the resource sharing through the exterior technical resource's internalization. This model can shorten the time of innovation, enhance their competitiveness, reduce cost of innovation, and spread the risk and so on. It includes cooperation between enterprises and enterprises, enterprises and universities or research institutions, setting up research institutes and other forms. While, using this model, strong relevance of technology and knowledge, fusion of the knowledge accumulating, supporting each other of the technological innovation system between the two sides are essential. Such as table 1.

\section{Insert Table 1 Here}

\section{Research on technical capacity promotion}

\subsection{Support of the government's policy}

Experience proves that, export-oriented private enterprises' development can not be separated from the promotion of government's policies. This article holds a view that the government ought to carry on the incline a little to export-oriented private enterprises, create loose external environment, support in the direction and so on. These policies include the financial policy support, the fiscal charge policy support, government's macro guidance, and softening terms of obtaining import and export right.

\subsection{Countermeasure of promoting themselves}

If export-oriented private enterprises develop in the international market, the necessary condition is national policy supporting and the necessary and sufficient condition is the improvement of their own technical capacity .Including:

\subsubsection{Raise awareness of enterprises}

Effectively raise awareness of recognition of technical innovation and the role of developing core competitiveness. Enhance innovation vitality of enterprises to ensure technology of sustainable development achieve. (Jiao, 2005, pp. 23-25).

\subsubsection{Introduction of advanced technology}

Concentrate on "reverse" investment to high-tech enterprises. Export-oriented private enterprises need to accelerate the introduction of advanced technology. They can seize and explore the international market by purchasing technology and attracting foreign investment to form their own development.

\subsubsection{Mergers and acquisitions}

On the basis of their own resources, export-oriented private enterprises get external innovation resources through the way of mergers and acquisitions to achieve external resources internal. Its essence is to achieve optimum combination 
of technical resources and realize independent innovation by property rights trading. Although costs and risks of this measure is higher, technical capacity of enterprises can be improved rapidly in a short time.

4.2.4 Make leading products as the center and develop a variety of technologies

When the leading products are well-selling in the market, enterprises should have a sense of crisis and develop products of the second or the third generation. When updating, guide the market with advanced technology (Yao, 2001, pp.36-39) and develop marketable products.

\section{Conclusions}

Developing export-oriented economy by the private enterprises is to meet the objective need of current international and domestic economic development. At present, because of weak ability of innovation and lack of technical advantages in overseas market, export-oriented private enterprises of our country are lack the stamina for development. Therefore, only establishing effective mechanisms of technical innovation and constantly improving their own technical innovation ability, export-oriented private enterprises can enhance core competitiveness and contribute for the sustainable development in the process of technology updating and adjustment of the national economy.

\section{References}

Jiao, Shouming. (2005). Analysis and choice of the mode of export-oriented enterprises entering international market. Qinghai Normal University Journal. 1, 23-25.

Mao,Yihua \& Chen, Jin. (2000). Development of technical capacity based on cooperation and innovation. The management of scientific research. 21, 4-6.

Yao, Zuowen \& Chen, Xiaojian. (2001). The development of research and technical capacity of High-tech enterprises. The management of research and development. 13, 36-39.

Zhang,Wenxue \& Liu, Longhai. (2001). The barrier and countermeasure of export-oriented development of Chinese private enterprises. Commercial Research, 58, 23-25.

Table 1. Conditions of different development model of the technical capacity

\begin{tabular}{|l|l|}
\hline \multirow{3}{*}{$\begin{array}{l}\text { Independent } \\
\text { innovation }\end{array}$} & To be qualified \\
\hline \multirow{4}{*}{$\begin{array}{l}\text { Cooperation } \\
\text { innovation }\end{array}$} & abundant fund \\
\cline { 2 - 2 } & strong capacity of researching and developing, some advantages \\
\cline { 2 - 2 } & rich accumulation of knowledge resources \\
\cline { 2 - 2 } & conformity different innovation resources effectively \\
\cline { 2 - 2 } & strong relevance of technology and knowledge between the two sides \\
\cline { 2 - 3 } & $\begin{array}{l}\text { fupion of the knowledge accumulating between the two sides } \\
\text { on }\end{array}$ \\
\hline
\end{tabular}




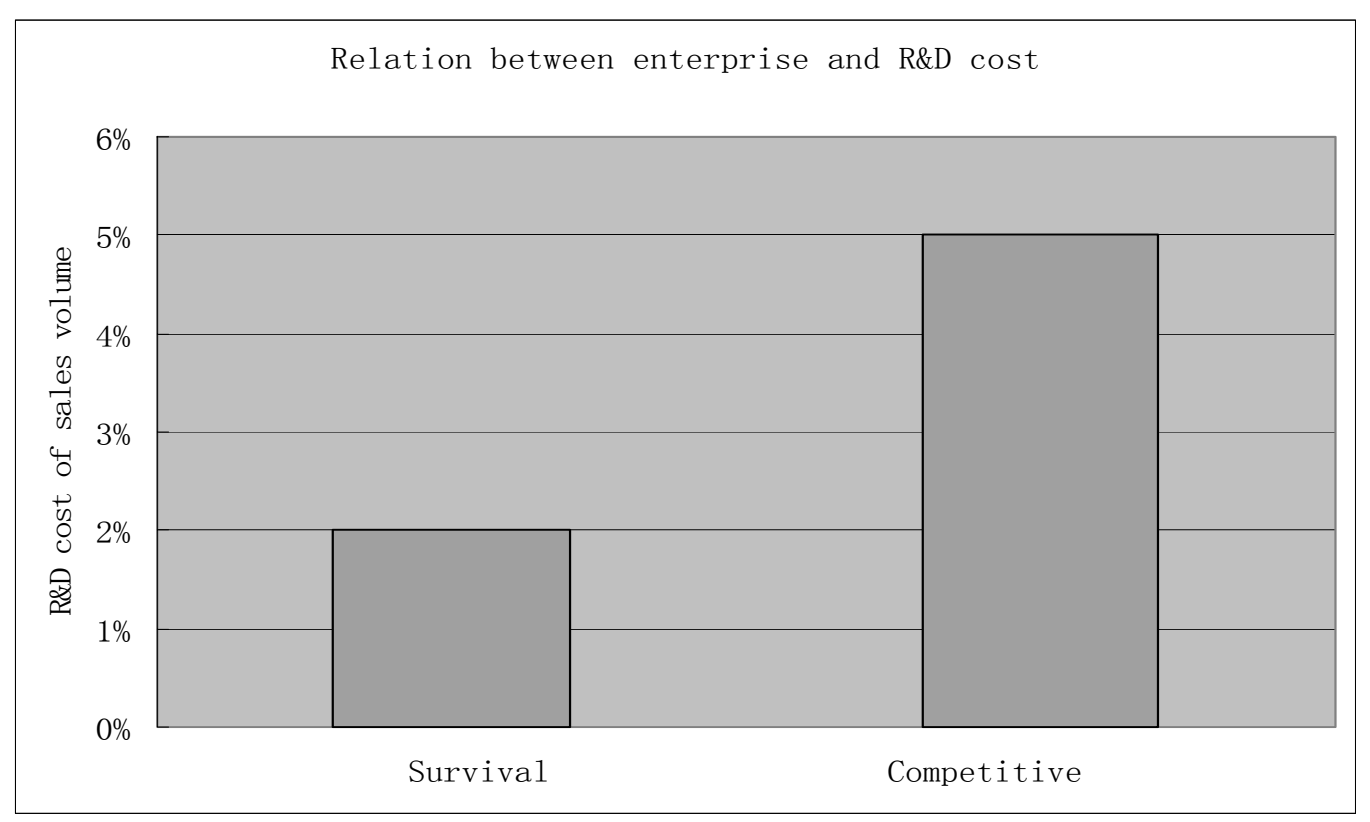

Figure 1. Relation between enterprise and R\&D cost 